\title{
PENGEMBANGAN MODUL PRAKTIKUM BIOLOGI YANG MEMANFAATKAN BAHAN ALAM SEBAGAI SUMBER BELAJAR BAGI SISWA DI SEKOLAH MENENGAH ATAS (SMA)
}

\author{
Mariana Rengkuan' ${ }^{1}$ \& Dian H. O. Howan ${ }^{2}$ \\ 1Jurusan Biologi \& ${ }^{2} J u r u s a n$ Kimia, Fakultas Matematika dan Ilmu Pengetahuan Alam, \\ Universitas Negeri Manado \\ mrgidionmaru@unima.ac.id
}

\begin{abstract}
Abstrak
The aim of this research is to generate biology laboratory work module which utilize natural products as learning resource for students in senior high school. This module developed using Borg and Gall model which has been adapted with the needs and aims of this research, therefore, it gained four major stages that will be passed. These stages namely: needs analysys and literature study, matter development (based on needs), expert validation and field test (experimental class). On expert validation limited to matter expert validator whilst for field test, it was decided on students from XII science class as experimental class. The result of this research shown that laboratory module that utilized natural products can be used as learning resource for students in senior high school.

Kata Kunci: Modul, bahan alam, pembelajaran.
\end{abstract}

\section{PENDAHULUAN}

Terdapat sejumlah permasalahan yang dihadapi anak didik di Sekolah Menengah Atas (SMA) sehingga belum menguasai materi pelajaran secara utuh.Hal ini dapat diuraikan sebagai berikut. Dalam pelaksanaan pembelajaran, guru belum mempersiapkan diri dengan baik seperti menyusun RPP dan menguasai materi yang akan diajarkan, guru belum mengunakan media pembelajaran yang sesuai dengan materi yang akan diajarkan, proses pembelajaran berlangsung monoton dan secara langsung. Guru mengalami kesulitan dalam mengimplementasi berbagai model pembelajaran. Evaluasi yang disusun guru untuk mengukur tingkat penguasaan siswa terhadap materi tersebut belum mengikuti standar evaluasi yang tepat seperti tingkat kesukaran soal dan daya pembeda soal.
Sarana prasarana yang tersedia di sekolah seperti laboratorium IPA yang sudah memenuhi standart minimal tidak diimbangi dengan kemampuan guru dalam menguasai dan menggunakan alat-alat laboratorium tersebut. Pada waktu menggunakan laboratorium, guru belum menyiapkan pedoman penggunaan laboratorium dan pedoman penilaian. Sehingga praktikum jarang dilakukan bahkan untuk beberapa kompetensi dalam mata pelajaran biologi tidak pernah dilakukan praktikum. Alasan yang dikemukakan oleh guru adalah: tidak tersedianya bahan kimia, sehingga konsep yang terbentuk pada siswa hanya sebatas hafalan.

Setelah dilakukan pengkajian lebih dalam lewat wawancara dengan beberapa guru biologi, disimpulkan bahwa guru 
belum menguasai beberapa konsep dalam materi genetik sehingga guru tidak dapat berimprovisasi dengan memanfaatkan sumber daya yang ada. Hal ini ditandai dengan kurangnya pengetahuan guru dalam memanfaatkan sumber daya alam atau bahan alam sebagai pengganti bahan kimia. Hal tersebut dikarenakan guru tidak mengetahui prinsip dasar dalam mempelajari konsep-konsep tersebut, padahal konsep-konsep tersebut sangat penting dalam mempelajari biologi. Berdasarkan hasil wawancara diketahui bahwa pada materi genetik dalam konsep kromosom, guru lebih memilih memberikan materi tersebut dalam bentuk ceramah dan tidak pernah melakukan praktikum, Imbasnya siswa tidak memiliki pengetahuan yang cukup pada materi ini karena tidak ada pengalaman langsung untuk melihat bentuk kongkrit dari kromosom.

Dengan demikian dibutuhkan sebuah model praktikum yang mudah, murah dan menyenangkan dalam membelakarkan konsep-konsep biologi. Model praktiukm ini kemudian dikemas menajdi sebuah modul praktikum yang dapat menajadi sumber belajar bagi siswa di Sekolah Menengah Atas (SMA).

\section{METODE PELAKSANAAN}

Penelitian ini merupakan penelitian pengembangan dalam rangka menghasilkan mudul praktikum pada Sekolah Menengah Atas (SMA). Tahapan penelitian meliputi: 180 need analysis dan Reference study, Material Development, Expert Validation, Try Out, Final Production. Lima langkash pengembangan tersebut merupakan modifikasi yang dilakukan dari 10 langkah yang ada pada model Borg and Gall (1983). Empat langkah pengembangan Model Borg \& Gall dapat dilihat dalam Gambar 1:

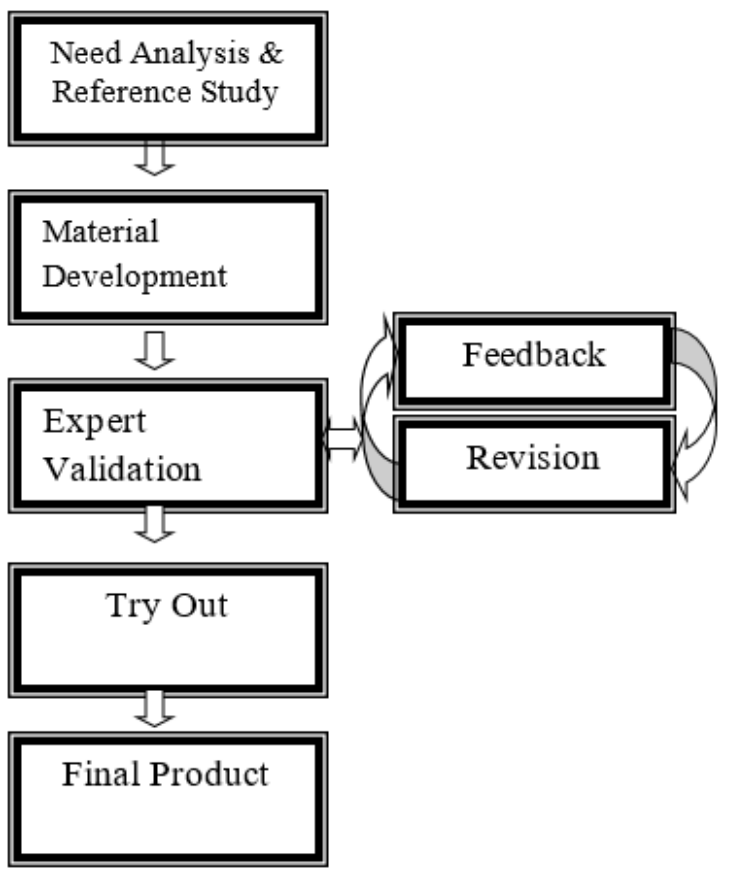

\section{Gambar 1. Langkah Pengembangan Model} Menurut Borg \& Gall

Data hasil pengembangan pada tahap penilian ahli isi kemudian di analisis menggunakan rumus sebagai berikut:

$$
\text { Persentase }=\frac{\sum \text { (jawaban } \mathrm{x} \text { bobot tiap pi }}{\mathrm{n} \times \mathrm{x} \text { bobot tertinggi }}
$$

Sementara data hasil try out pada siswa di SMA N 1 Tondano yang diperoleh melalui penelitian tindakan kelas, dengan Prosedur penelitian tindakan kelas ini terdiri dari 2 siklus. Siklus pertama pada materi pencemaran dan siklus kedua pada materi 
limbah. Tiap siklus dilaksanakan dengan prosedur: (1) perencanaan tindakan, (2) pelaksanaan tindakan, (3) observasi, dan (4) refleksi. Dari data hasil PTK dihitung untuk menentukan persentase keberhasilan, cara penghitungannya melalui rumus:

$\%$ Keberhasilan $=\frac{\sum \text { Skor yang dicapai }}{\sum \text { Skor maksimum }} X 100$

\section{HASIL DAN PEMBAHASAN}

Penelitian ini menghasilkan Modul praktikum yang berbasis bahan alam. dikembangkan dari sebuah uji coba laboratorium yang telah dilakukan oleh peneliti untuk mendapatkan formula yang tepat. Hasil penilaian produk berupa modul praktikum yang berhasil dikembangkan oleh pengembang dapat dilihat pada Tabel 1.

Tabel 1. Hasil Penilaian Ahli Isi terhadap Penuntun Ptraktikum melalui Angket

\begin{tabular}{|l|l|c|}
\hline No & \multicolumn{1}{|c|}{ Kriteria } & Skor \\
\hline 1. & $\begin{array}{l}\text { Kejelasan petunjuk umum } \\
\text { praktikum (larangan, kewajiban, } \\
\text { peringatan) }\end{array}$ & 4 \\
\hline 2. & $\begin{array}{l}\text { Kejelasan pengenalan alat dan } \\
\text { bahan praktikum }\end{array}$ & 4 \\
\hline 3. & $\begin{array}{l}\text { Kesesuaian antara pendahuluan } \\
\text { dengan materi praktikum }\end{array}$ & 3 \\
\hline 4. & $\begin{array}{l}\text { Kesesuaian antara tujuan } \\
\text { praktikum dengan materi } \\
\text { praktikum Tujuan }\end{array}$ & 4 \\
\hline 5. & $\begin{array}{l}\text { Keoperasionalan } \\
\text { Pembelajaran Khusus }\end{array}$ & 4 \\
\hline 6. & $\begin{array}{l}\text { Ketepatan langkah-langkah } \\
\text { (prosedur) praktikum }\end{array}$ & 4 \\
\hline 7. & Kejelasan petunjuk umum & 3 \\
\hline 8. & Kejelasan tugas dan latihan \\
\hline & \multicolumn{1}{|c|}{ Jumlah } \\
\hline
\end{tabular}

Pada penuntun praktikum, ada beberapa hal yang disarankan oleh ahli isi mata kuliah. Saran-saran dan komentar yang diberikan oleh ahli isi mata kuliah adalah sebagai berikut:

1) Idenya sudah baik sekali, namun perlu direvisi cara penulisan, agar mudah dipahami;

2) Soal dan latihan perlu diberikan untuk setiap bagian praktikum;

3) Setiap bab diberikan pendahuluan; dan

4) Sumber penunjang perlu dicantumkan.

Langkah berikut yang dilakukan setelah data disajikan adalah menganalisis data. Berdasarkan hasil penelitian ahli isi sebagaimana dicantumkan dalam tabel 1 , maka dapat dihitung persentase tingkat pencapaian modul praktikum sebagai berikut:

$$
\text { Persentase }=\frac{\sum \text { (jawaban } \mathrm{x} \text { bobot tiap pi } \mathrm{i}}{\mathrm{n} \times \text { bobot tertinggi }} \times 100 \%
$$

Karena bobot tiap pilihan adalah 1, maka persentase $=57:(15 \times 5) \times 100 \%=$ 76\%. Setelah dikonversikan dengan tabel konversi, persentase tingkat pencapaian $76 \%$, berada pada kualifikasi baik, sehingga modul praktikum tidak perlu direvisi.

Selanjutnya Modul yang sudah dikembangkan di uji coba pada siswa dengan menggunana model Penelitian Tindakan Kelas (PTK) yang terdiri atas dua siklus. Hasil siklus 1 dan 2 dapat dilihat pada tabel 2. Berikut ini proses pelaksanaan praktikum berbasis bahan alam di SMA N 1 Tondano (Gambar 1).

Berdasarkan data yang terdapat pada Tabel 2, untuk data awal diperoleh dari tes awal pembelajaran, siklus I 
diperoleh dari tes akhir pada materi struktur, sifat, fungsi DNA, gen dan kromosom. Dari Tabel 2 dapat diketahui bahwa rata-rata skor awal sebesar 48,6 dan
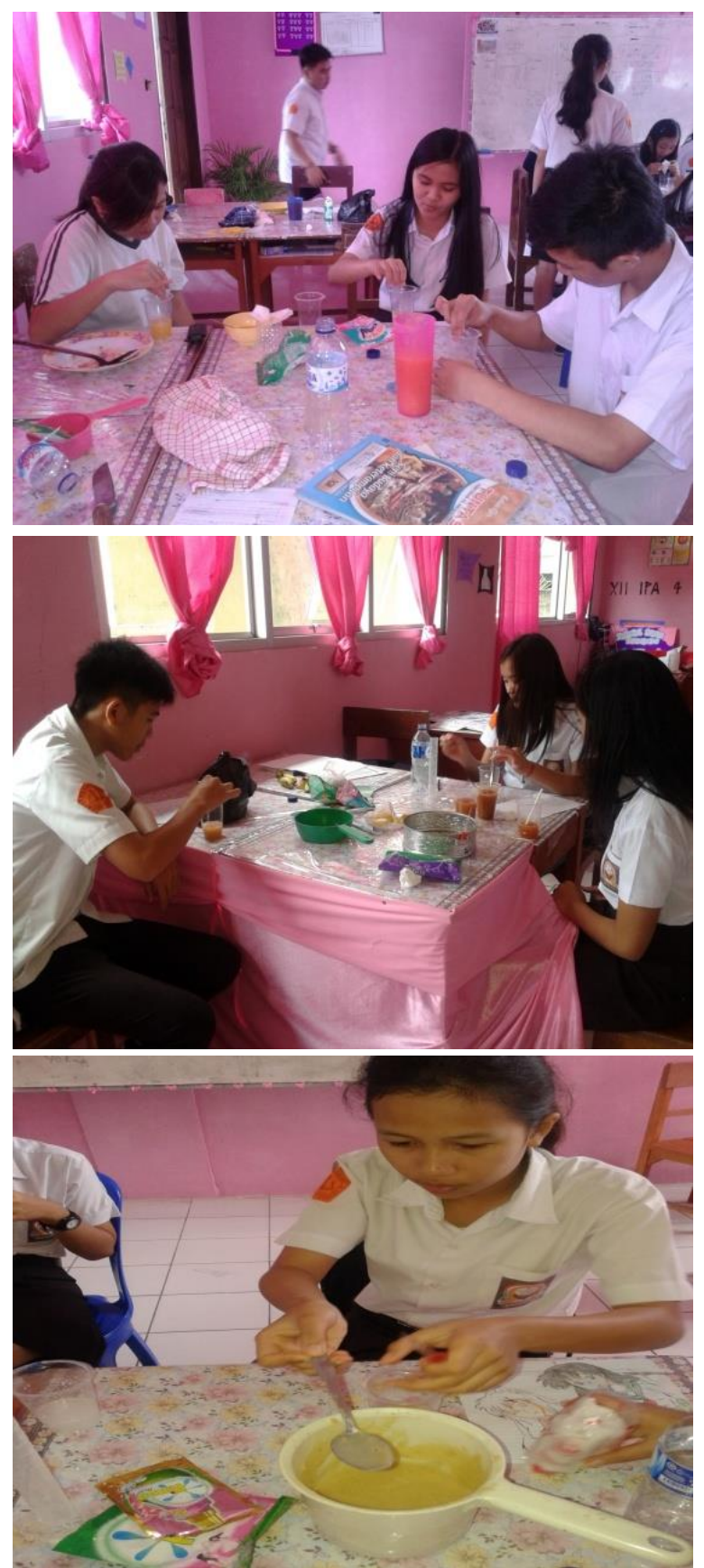

Gambar 1: Implementasi Model Praktikum pada Siswa XII IPA di SMA N 1 Todano melalui Penelitian Tindakan Kelas

Jika dilihat dari ketuntasan belajar minimal tiap individu, terdapat 5 siswa yang sudah tuntas dalam belajar yang 182

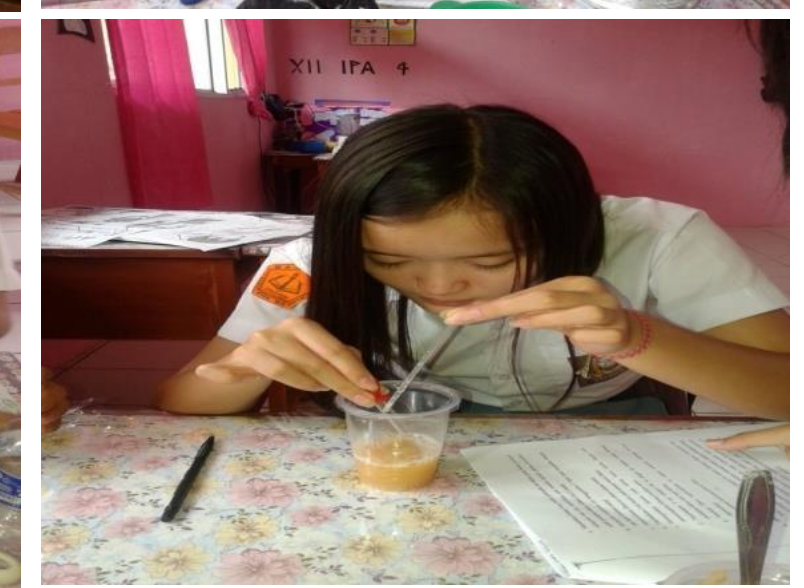

rata-rata skor siklus I sebesar 52,72. Berdasarkan data tersebut diketahui ada peningkatan rata-rata skor dari data awal ke siklus I sebesar 4,12 poin.
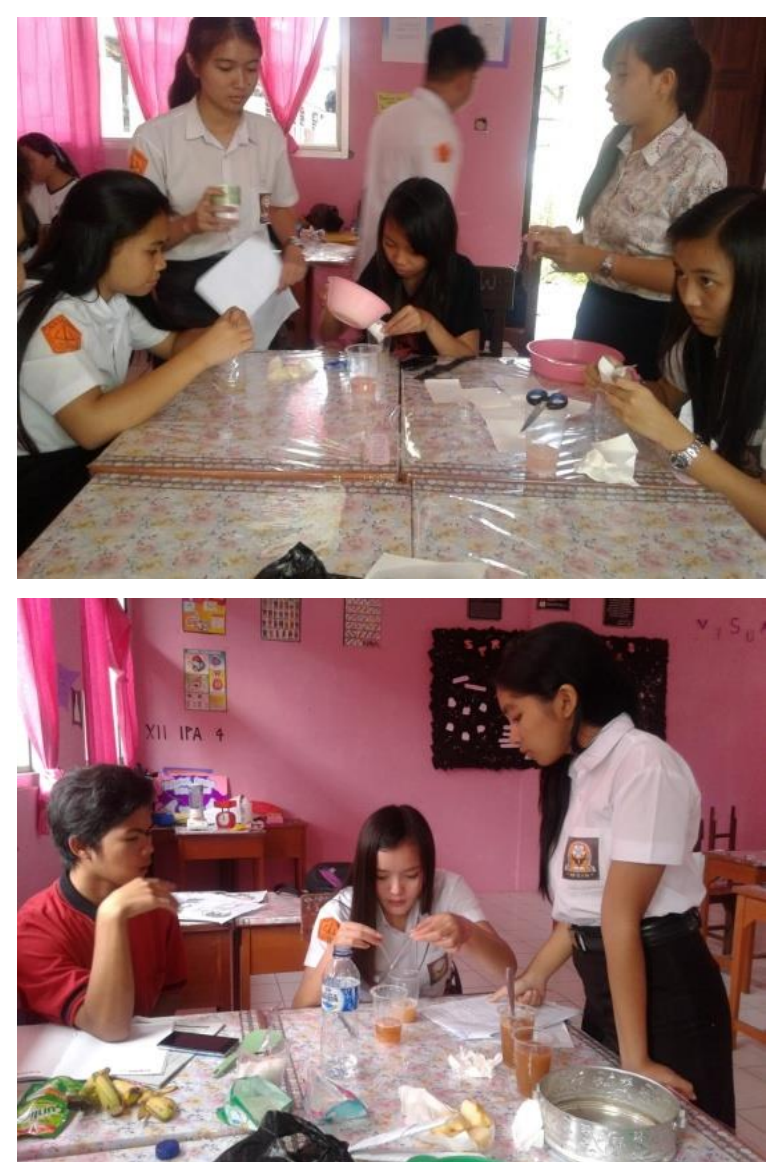
Sedangkan jika dilihat dari persen belajar minimal siswa secara klasikal sebesar $22,72 \%$ dari jumlah siswa yang memperoleh nilai > 70 maka siswa kelas XII-IPA SMA N 1 Tondano masih belum tuntas karena persen jumlah siswa yang tuntas belajar adalah 22,72\% (5 siswa) dan masih terdapat 77,27\% (17 siswa) yang belum tuntas. Hal ini masih belum menunjukkan ketuntasan minimal belajar secara klasikal sebesar $75 \%$ yang ditentukan sekolah sebagai standar ketuntasan belajar minimal secara klasikal.

Tabel 2 Hasil Uji Coba Modul Praktikum yang Memanfaatkan Sumber daya Alam

\begin{tabular}{|c|c|c|c|c|}
\hline \multirow[b]{2}{*}{ No } & \multirow[b]{2}{*}{ Nama } & \multicolumn{3}{|c|}{ Skor } \\
\hline & & Awal & $\begin{array}{c}\text { Siklus } \\
1\end{array}$ & $\begin{array}{l}\text { Siklus } \\
2\end{array}$ \\
\hline 1 & Pingkan D. Laloan & 40 & 50 & $80 *$ \\
\hline 2 & Ronaldo Mussu & 50 & 40 & 70 \\
\hline 3 & $\begin{array}{l}\text { Ni Made } \\
\text { Netriviana }\end{array}$ & 50 & 60 & $80 *$ \\
\hline 4 & Prayri Tulandi & 40 & 40 & $75^{*}$ \\
\hline 5 & Ronaldi Soselisa & 40 & 50 & $80^{*}$ \\
\hline 6 & Mikhael Ch Mumu & 40 & 50 & $75^{*}$ \\
\hline 7 & Rivaldo Kowaas & 50 & 60 & $75^{*}$ \\
\hline 8 & Miracle Matindas & 50 & 50 & $80^{*}$ \\
\hline 9 & Richard Samoia & 30 & 30 & 70 \\
\hline 10 & Mega R. Tompoh & 30 & 30 & $75^{*}$ \\
\hline 11 & Nanda Tooleng & 60 & $75^{*}$ & $75^{*}$ \\
\hline 12 & Melany Kumayas & 60 & $70^{*}$ & $75^{*}$ \\
\hline 13 & Olivia M. Nanlohy & 60 & $75^{*}$ & $80 *$ \\
\hline 14 & $\begin{array}{l}\text { Monica } \\
\text { Mokoagow }\end{array}$ & 30 & 30 & $75^{*}$ \\
\hline 15 & Mersy Manengkey & 60 & 60 & $80^{*}$ \\
\hline 16 & Nikita S. Tinagon & 50 & 50 & $75^{*}$ \\
\hline 17 & Silvia Hillary & 80 & $80^{*}$ & $80^{*}$ \\
\hline 18 & Priskilla Wowor & 40 & 40 & $85^{*}$ \\
\hline 19 & $\begin{array}{l}\text { Revol G. } \\
\text { Pangerapan }\end{array}$ & 40 & 40 & $90^{*}$ \\
\hline 20 & $\begin{array}{l}\text { Putri M. M. } \\
\text { Rotikan }\end{array}$ & 50 & 50 & $85^{*}$ \\
\hline 21 & $\begin{array}{l}\text { Novia } \\
\text { Lumingkewas }\end{array}$ & 60 & 60 & $90^{*}$ \\
\hline 22 & $\begin{array}{l}\text { Queenshe } \\
\text { Pinangkaan }\end{array}$ & 60 & $70^{*}$ & $90^{*}$ \\
\hline Jum & & 1070 & 1160 & 1740 \\
\hline Rat & -rata Skor & 48,6 & 52,72 & 79,1 \\
\hline
\end{tabular}

Berdasarkan data hasil skor pada siklus pertama maka dilanjutkan siklus kedua pada materi berikut, yaitu: struktur, sifat dan fungsi RNA. Pada siklus kedua ini terjadi peningkatan hasil pembelajaran, dimana diperoleh skor rata-rata mencapai 79,1 dengan selisih antara skor pada siklus 1 adalah 26,38. Pada siklus kedua ini diperoleh ketuntasan belajar minimal klasikal sebesar 90,9\% (20 siswa).

Berdasarkan hasil ujian diketahui bahwa ada dua siswa yang masih belum tuntas belajar. Oleh karena itu siswa melakukan pembelajaran remidi di luar jam pelajaran. Pembelajaran remidi dilakukan oleh anggota kelompok yang mempunyai nilai tertinggi membantu anggota kelompoknya yang belum tuntas belajar dibimbing oleh peneliti. Dalam pembelajaran ini siswa yang belum tuntas belajarnya mendiskusikan kembali pertanyaan-pertanyaan yang ada di LKS kemudian guru memberikan tes dengan soal yang sama.

Peningkatan hasil belajar dapat terjadi karena siswa mengkonstruksi pengetahuan mereka secara langsung lewat praktikum berbasis bahan alam lewat kerja laboratorium. Kerja laboratorium ini memungkinkan guru dan siswa bekerja secara konkret, misalnya pada materi genetika dengan mengisolasi DNA total yang menggunakan perlatan dasar dan juga metode yang sama degan yang dugunakan para ilmuwan (Dollard, 1994). 
Prosedur yang dilakukan merupakan hasil modifikasi yang telah dilakukan secara luas di laboratorium bioteknologi, namun prosedur ini menggunakan alat dan bahan pengganti (bahan alternatif) yang memiliki fungsi yang sama dengan alat dan bahan yang digunakan oleh para ilmuwan. Alat dan bahan ini dengan mudah dapat ditemukan dalam kehidupan sehari-hari siswa sehingga dapat menimplementasikan model pembelajaran CTL (Contextual Teaching and Learning) dalam kegiatan pembelajaran. Hal yang menarik dalam praktikum ini adalah penggunaan bahanbahan alami yang mudah ditemukan disekitar siswa dan memiliki fungsi sama dengan bahan-bahan kimiawi.

Pada dasarnya, ada beberapa hal yang bisa dimodifikasi dalam penelitian mengenai isolasi DNA, antara lain: 1) sumber DNA yang diisolasi dapat menggunakan DNA dari berbagai macam buah atau sejenisnya, 2) alat dan bahan yang digunakan untuk merusak dinding dan membran sel, misalnya macam-macam detergent yang berfungsi hampir sama dengan EDTA yang berfungsi untuk melisiskan barier (penghalang) sel secara kimiawi untuk merusak dinding sel, 3) sumber enzim protase maupun ekstrak yang mengadung enzim protase, misalnya buah nenas, 4) penggunaan garam dapur untuk memekatkan DNA karena ion $\mathrm{Na}+$ yang dikandung oleh garam mampu memblokir (membentuk ikatan) dengan 184 kutub negatif fosfat DNA, yaitu kutub yang biasa menyebabkan molekul-molekul salng tolak menolak satu sama lain sehingga DNA akan berkumpul.

\section{KESIMPULAN DAN SARAN}

Berdasarkan pengalaman langsung oleh siswa yang digambarkan di atas maka dapat diketahui bahwa dengan menciptakan sebuah kerja laboratorium yang murah, nudah dan menyenakan yang dikemas dalam bentuk modul praktikum dapat meningkatkan hasil belajar siswa di Sekolah Menengaha Atas (SMA).

\section{KEPUSTAKAAN}

Anonym a.2005.DNA Extraction from Wheat Germ, (Online), (The University of Utah).http://www.gslc.genetics.utah.e $\mathrm{du} /$ units/activities/wheatgerm.html

Arsyad, Azhar. 2002. Media Pembelajaran. Jakarta:PT. Raja Grafindo Persada.

Borg R., W \& Gall M., D . 1983.Fourth Edition: Educational Research an Introduction. New York; Longman

Corebian A.D.2003.Pembelajaran Kontekstual.Departemen Pendidikan Nasional

Davidson, Marry.1991.DNA Extrtion(online), http://www.accessexxellence.org/AE /AEPC/1991/dna.html

Direktorat Gizi.1981.Daftar Komposisi Bahan Makanan:Jakarta.Departemen Kesehatan Republik Indonesia.

Dollard, Kate.1994.DNA Isolation, (online), http://www.accessexxellence.org/AE /AEPC/1991/dollard.onionDNA.html

Ghazali, A.S.2002.Menciptakan Lingkungan Pembelajaran Kooperatif Konstruktivistik.Makalah Disajikan 
pada lokakarya Pengembangan Model Pembeljaran dengan Pradigma

Konstruktivisme untuk Dosen Universitas Negeri Malang dan GuruGuru SLTP Kota Malang

Ibrahim, Muslimin.2002.Teori Belajar Konstrutivisme.Departemen Pendidkan Nasional

Nurhadi dan Senduk, A.G.Pembelajaran Kontekstual(Contextual teaching and
Learning/CTL) dan penerapannya dalam KBK.Malang UM Press

Sadiman, Arief, dkk.2003.Media Pembelajaran (pegertian, pengembangan dan pemanfaatannya).Jakarta:PT. Raja Grafindo Persada

Subyianto.1990.Strategi Beajar Mengajar Ilmu Pengetahuan Alam. Malang: Penerbit IKIP Malang 
Jurnal ABDIMAS, Vol. 9, No. 2, Desember 2016

ISSN: 1979-0953 